\title{
Relationship between hydraulic properties and plant coverage of the closed-landfill soils in Piacenza (Po Valley, Italy)
}

\author{
C. Cassinari ${ }^{1}$, P. Manfredi ${ }^{2}$, L. Giupponi ${ }^{3}$, M. Trevisan ${ }^{1}$, and C. Piccini ${ }^{4}$ \\ ${ }^{1}$ Istituto di Chimica Agraria ed Ambientale, Università Cattolica del Sacro Cuore, \\ Via Emilia Parmense 84, 29122 Piacenza, Italy \\ ${ }^{2}$ m.c.m. Ecosistemi s.r.l. località Faggiola, 29027 Gariga di Podenzano, Piacenza, Italy \\ ${ }^{3}$ Centro Interdipartimentale di Studi Applicati per la Gestione Sostenibile e la Difesa della Montagna, Università della \\ Montagna, Università degli Studi di Milano, Via Morino 8, 25048 Edolo, Brescia, Italy \\ ${ }^{4}$ CRA Consiglio per la Ricerca e la Sperimentazione in Agricoltura, Centro di ricerca per lo studio delle relazioni tra pianta e \\ suolo, Via della Navicella 2-4, 00184 Rome, Italy
}

Correspondence to: C. Cassinari (chiara.cassinari@unicatt.it)

Received: 13 January 2015 - Published in Solid Earth Discuss.: 20 February 2015

Revised: 2 July 2015 - Accepted: 7 July 2015 - Published: 28 July 2015

\begin{abstract}
In this paper the results of a study of soil hydraulic properties and plant coverage of a landfill located in Piacenza (Po Valley, Italy) are presented, together with the attempt to relate the hydraulic properties in relation with plant coverage. The measured soil water retention curve was first compared with the output of pedotransfer functions taken from the literature and then compared with the output of the same pedotransfer functions applied to a reference soil. The landfill plant coverage was also studied. The relationship between soil hydraulic properties and plant coverage showed that the landfill soils have a low water content available for plants. The soils' low water content, together with a lack of depth and a compacted structure, justifies the presence of a nitrophilous, disturbed-soil vegetation type, dominated by ephemeral annual species (therophytes).
\end{abstract}

\section{Introduction}

Soil water is a fundamental resource for the components of the ecosystem; it plays a vital role in determining the functioning of plants and other soil biota (Brevik et al., 2015). Soil physics is largely related to the interaction between soil and water; therefore the physical, chemical and biological processes that take place in soil depend on the amount and composition of water (Brevik et al., 2015). With this in mind, knowledge of the hydraulic properties of soils is important in many scientific disciplines, from agriculture to ecology, since the amount of water, and the strength by which it is held by soil, represents the characteristics of soil behaviour and for the vegetation and all other organisms' development.

Land use can significantly affect soil properties, such as bulk density, saturated hydraulic conductivity, infiltration rate and available soil water content (Haghighi et al., 2010), and it has been shown to be one of the main factors controlling soil water variability (Qui et al., 2001; Pan and Wang, 2009). Because soil properties are the main factor controlling soil water variation (Vachaud et al., 1985, Famiglietti et al, 1998; Hu et al., 2010), land use could influence soil water variations by changing soil properties (Gao et al, 2014). In recent studies, the effects of land use on soil water variation have been investigated via statistical analysis (Fu et al., 2003; Chen et al., 2007; Gross et al., 2008), simulation, or physicalbased models (Li et al., 2009). Gao et al. (2014) demonstrate, through a study in a small catchment of the Chinese Loess Plateau, that land use can lead to spatial variation of soil water but has a negligible effect on soil water temporal patterns.

Soil moisture influences soil behaviour; it takes an important role, for example, in soil erosion. Antecedent soil moisture content, together with rainfall intensity, slope steepness and land use/land cover are factors influencing soil erosion and runoff (Ziadat and Taimeh, 2013). The effect of antecedent soil water content on soil erosion is still a matter of debate, as an opposing effect has been reported on aggre- 
gate breakdown and seal formation (Vermang et al., 2009). Wet soils double the runoff coefficient and shorten the time to runoff, compared with the same soil when dry (Li et al., 2011). Greater soil erosion was observed during the wet season in Spain (Cerdà, 2002; Ziadat and Taimeh, 2013).

Soil water/moisture is also a key factor affecting vegetation structure in a water-limited environment (RodriguezIturbe et al., 1999); in turn, vegetation exerts vital control on the entire water balance (Rodriguez-Iturbe et al., 2001) via complex and mutually interacting hydrological processes (Porporato et a., 2002; Gao et al. 2014).

In this paper, the study of hydraulic properties of soil is presented, by laboratory analysis, by using predictive models and by studying soil vegetation cover.

Direct measurements of soil hydraulic properties are rarely performed because they require lengthy and costly analysis; as an alternative, analysis of existing databases of measured soil hydraulic data may result in pedotransfer functions (PTFs) (Wösten et al., 2001). These functions often prove to be good predictors for missing soil hydraulic data. The PTFs show empirical relationships between soil hydraulic properties and some more easily measurable basic soil properties such as texture, bulk density and organic carbon content (Baker, 2008; Bouma and van Lanen, 1986; Pachepsky and Rawls, 2004; Vereecken et al., 2010; Wösten et al., 2001). To derive the PTFs, databases of soils from all over the world were used. Generally soil databases emphasize soil taxonomy and provide limited unsaturated soil hydraulic data. With this in mind, the international Unsaturated Soil Database (UNSODA) (Leij et al., 1996) and subsequently, the European database of soil hydraulic properties (HYPRES) (Nemes et al., 2001a; Wösten et al., 1999; Wösten and Lilly, 2004) were developed. Both these databases contain a wealth of information about soil hydraulic data, measurement methods and other relevant soil data (Nemes et al., 2001a).

The processing of the PTFs can be performed using computer programs such as CalcPTF 3.0 (Guber and Pachepsky, 2010), ROSETTA (Schaap M.G., et al., 2001) (which is available as stand-alone program and also as a part of the simulation model HYDRUS 1D; Simunek, et al., 2008), SOILPAR (Acutis and Donatelli, 2002) and SPAW (Saxton and Willey, 2006).

The relationship between volumetric water content and matric potential is shown by the soil water retention curve, which allows the derivation of available water for plants by comparing the water content at different applied suction (negative pressure) values.

In recent decades the increase in human population and human activity has resulted in an ongoing depletion of soil resources, to the point that the authorities have included the recovery of degraded areas in their priorities. The lower ability to make water available for plants and microorganisms is characteristic of a degraded soil; thus, in order to carry out soil restoration, it is important to know its hydraulic properties.

In this work a degraded cover soil of a landfill located in Piacenza was studied. The soil used to closed the landfill is a natural soil, which comes from different areas near Piacenza, and it can be classified as an Anthrosol (FAO World Reference Base for Soil Resources): a soil formed or profoundly modified through long-term human activity, such as from addition of organic waste or household waste, irrigation or cultivation. This soil has shown very low fertility for more than 30 years; there is no chemical contamination justifying its condition, so the soil can be described as a degraded soil.

Recently the landfill soils and the vegetation were studied, and so the site environmental quality is described, including the relationship between soil chemical analysis and ecological indicators (Manfredi et al., 2012), the floristicvegetational indexes (Giupponi et al., 2013b) and the presence and development of Onopordum acanthium subsp. acanthium (Giupponi et al., 2013a). The area is actually involved in a Life + project (Life $10 \mathrm{ENV/IT/000400}$ New Life, http://www.lifeplusecosistemi.eu), which includes among its objectives the treatment of degraded soils through an innovative reconstitution method to improve their quality, and the restoration of the closed landfill.

Restoration of closed landfills is essential to minimize the adverse effect on the environment and to render the landfills safe for further use (Chen et al., 2015). A lot of studies on landfills can be found in the literature - about root contamination by gas (Gilman et al., 1982), methane production (Themelis and Ulloa, 2007), microbiological studies (Boeckx et al., 1996) and ecological performance after the restoration of plant and animal communities (Chen et al., 2015; Wong et al., 2015) - but nothing can be found about hydrological properties of cover soil in relation to plant coverage.

The study of the vegetation cover of an area can be very useful as a tool to compare and corroborate the results of chemical and physical analysis performed on soil. The integrated study of different scientific disciplines in the description of an area is always preferred in order to have as complete an overview as possible. The study of the relationship between soil hydraulic properties and plant coverage, and the use of plant communities to assess the soil quality is a very interesting research field. This new way of studying an area can be applicable not only in describing degraded areas, but also when applied in other research fields, such as rural areas, road embankments, mining, badlands or border areas.

Novara et al. (2011) demonstrate that an appropriate choice of cover crops assists in very effective soil management in vineyards in Sicily. A natural reforestation following a different land use on the flood plain in the Dragonja sedimentation basins has resulted in a change in sedimentation rate (Keesstra, 2007; Keesstra et al., 2009). A study performed in a restoration program in South East New Territories landfill in Hong Kong, between pioneer species and 
native species - including the investigation of different planting techniques, the use of different types of soil ameliorants and a focus on understanding what factors are most important in the growth of plants - provided valuable information for restoring subtropical engineering landfills (Wong et al., 2015). The vegetation, climate and environmental change have been used to explain the reasons of the severe soil erosion in the Loess Plateau of China (Zhao et al., 2013). Zornoza et al. (2015) use vegetation cover for the development of an index to assess the state of human disturbances in alpine grassland with different levels of degradation based on plant cover, production, proportion of primary plant and height of the plant. Studies of the vegetation biodiversity, together with chemical and physical soil analyses and the testing of the presence/abundance of soil microbes and soil fauna, are also used to assess the soil quality in some farms in Iceland and Austria (van Leeuwen et al., 2015).

Considering the importance of soil moisture and vegetation cover, the aim of this work is to relate the hydraulic properties of landfill soil with its vegetation, and to assess whether predictive systems (PTFs) are suitable for predicting these data.

\section{Materials and methods}

\subsection{Study area}

The closed landfill of municipal solid waste of Borgotrebbia is located in the territory of Piacenza (Po Valley, Italy, coordinates: $45^{\circ} 03^{\prime} 58^{\prime \prime} \mathrm{N}, 09^{\circ} 39^{\prime} 06^{\prime \prime} \mathrm{E}$ ) at an altitude of $60 \mathrm{~m}$. It has an area of $200000 \mathrm{~m}^{2}$ and is located along the right bank of the Trebbia River near its confluence with the Po River. Climatic data show that the average annual temperature is $13.3^{\circ} \mathrm{C}$, while the average annual rainfall amounts to $778 \mathrm{~mm}$, most of which is concentrated in the periods of March and September.

The landfill was opened from 1972 to 1985 and then was closed and covered with a layer, about $50 \mathrm{~cm}$ in depth, of different degraded soils left to be spontaneously colonized by plants. The soils used to close the landfill are loamy soils with a predominantly multi-faceted structure; they have low porosity and, by their nature, they are compact. Further compaction of the soil was induced by compression, caused by operations carried out in order to close the landfill so that the leakage of gas and infiltration by rain could be avoided.

\subsection{Soil}

\subsection{Physical-chemical analysis of the soil}

Eleven sampling points were chosen as being representative of the closed landfill area after a preliminary study. Initially they were sampled in the area at 51 points, following a grid division NE-SW, NW-SE; and the distribution of the observed different vegetation types - the plant communities dif- fer in structure and floristic composition according to the different environmental factors such the type of soil. By statistical elaboration of the 51 chemical analyses, 11 soils resulted in being the most representative of the area.

The 11 soil samples were taken at $25 \mathrm{~cm}$ depth and chemical and physical analyses were carried out based on the Methods of Soil Chemical and Physical Analysis as described in the Official Gazette of the Italian Republic: texture and grain size (Italian position Method II.5 Suppl. Ord. G.U. no. 248/21.10.1999; international position ISO 11277), primary and secondary structure, organic carbon (Italian position Method VII.3, Suppl. Ord. G.U. no. 248/21.10.1999, Walkley-Black,), salinity (Italian position Method IV.1 Suppl. Ord. G.U. no. 248/21.10.1999, international position ISO 11265 , aqueous extract $5: 1$ ), total limestone (Italian position Method V.1, Suppl. Ord. G.U. no. 248/21.10.1999, international position ISO 10693) and water potential (Italian position Method VIII.3, Suppl. Ord. G.U. no. 173/02.09.1997, international position ISO/DIS 11274, sand box and Richards plates; measurements performed on undisturbed samples). The results of the physical-chemical analyses were used as input for the elaboration of 18 different PTFs (Tables 1 and 2). As the bulk and particle density of samples aren't measured, the literature values for loamy soils were used: bulk density $1.3 \mathrm{~g} \mathrm{~cm}^{-3}$ and particle density $2.3 \mathrm{~g} \mathrm{~cm}^{-3}$.

\subsubsection{Water retention models}

Most mathematical models that describe soil hydrologic behaviour are based on non-linear relationships between the volumetric water content in the soil, $\theta$, the suction applied by the soil, $h$, and the hydraulic conductivity (Hillel, 1998); the functions $\theta(h)$ and $K(h)$ describe the hydraulic properties of a soil through a parametric equation (Leij et al., 1997). Some predictive methods for estimating hydraulic conductivity are based on direct observations of water content in the soil measured at different values of suction (Romano and Palladino, 2002). To compensate for all the cases in which it is not possible to measure it, a group of functions called pedotransfer functions (PTFs) has been developed. PTFs correlate the water retention and hydraulic conductivity with some easily measurable chemical and physical properties of the soil such as texture, density, porosity, and organic carbon content (Elsenbeer, 2001; Tietje and Hennings, 1996; Tapkenhinrichs and Tietje, 1993). Most PTFs are regression equations that are derived from data collected during specific campaigns and are reliable for describing the soil hydraulic properties (Romano and Palladino, 2002).

In this work, the measured water retention curves were compared with those obtained using 17 PTFs proposed in the literature that are based on databases of soils distributed worldwide following two models: Brooks and Corey (1964) and van Genuchten (1980), (Rawls et al., 1998, 1992, 1982a; Saxton and Rawls, 2006; Saxton et al., 1986; Tanij, 1990). 
Table 1. Results of chemical and physical analyses performed on soils. Legend: A.B.: angular blocky; Sa.B.: subangular blocky; G.: granular; P.: platy; S.G.: single grain.

\begin{tabular}{llrlrrrrl}
\hline Sample & $\begin{array}{l}\text { Organic } \\
\text { carbon } \\
\text { content } \\
\%\end{array}$ & $\mathrm{CaCO}_{3}$ & $\begin{array}{l}\text { Electrical } \\
\text { conductivity }\end{array}$ & Sand & Silt & Clay & $\begin{array}{l}\text { Soil } \\
\text { thickness }\end{array}$ & $\begin{array}{l}\text { Structure } \\
\text { of soil }\end{array}$ \\
& $\mathrm{g} \mathrm{kg}^{-1}$ & $\mathrm{ds} \mathrm{m}^{-1}$ & $\%$ & $\%$ & $\%$ & $\mathrm{~cm}$ & \\
\hline 1 & 1.94 & 130.2 & 0.197 & 21.9 & 12.3 & 65.8 & 55 & A.B.-Sa.B. \\
2 & 4.13 & 147.7 & 0.212 & 17.5 & 12.9 & 69.6 & 30 & G.-Sa.B. \\
3 & 4.14 & 190.4 & 0.152 & 27.9 & 12.3 & 59.8 & 60 & G.-Sa.B. \\
4 & 1.67 & 38.5 & 0.232 & 11.5 & 14.7 & 73.8 & 30 & Sa.B.-G. \\
5 & 1.04 & 134.8 & 0.167 & 12.2 & 12.4 & 75.4 & 62 & P. \\
6 & 1.35 & 57.4 & 0.196 & 10.3 & 14.7 & 75 & 32 & Sa.B.-G. \\
7 & 1.92 & 229.8 & 0.130 & 33.3 & 12.5 & 54.2 & 45 & S.G.-Sa.B. \\
8 & 4.10 & 266.7 & 0.288 & 16.7 & 16.8 & 66.5 & 47 & A.B.-G. \\
9 & 2.35 & 138.1 & 0.252 & 25 & 12.3 & 62.7 & 47 & A.B.-Sa.B. \\
10 & 2.68 & 59.9 & 0.136 & 18 & 9.8 & 72.2 & 50 & Sa.B.-A.B. \\
11 & 3.63 & 128.9 & 0.248 & 17.8 & 12.3 & 69.9 & 40 & Sa.B.-G. \\
\hline
\end{tabular}

Table 2. Volumetric water content $(\theta \%)$ from instrumental analysis at different suction values.

\begin{tabular}{lllllllll}
\hline Sample & \multicolumn{7}{c}{ Suction $(-\mathrm{kPa})$} \\
\cline { 2 - 9 } & 0.10 & 0.25 & 1 & 3 & 6 & 10 & 33 & 1500 \\
\hline 1 & 49.45 & 43.58 & 39.21 & 37.23 & 35.88 & 34.54 & 27.60 & 24.66 \\
2 & 48.75 & 44.27 & 41.05 & 38.62 & 37.61 & 36.98 & 28.46 & 27.91 \\
3 & 47.77 & 45.12 & 41.83 & 37.00 & 34.80 & 33.83 & 25.71 & 13.57 \\
4 & 49.42 & 45.87 & 40.40 & 35.46 & 32.77 & 31.13 & 22.91 & 22.32 \\
5 & 44.09 & 41.77 & 37.31 & 33.07 & 31.20 & 30.01 & 21.73 & 18.92 \\
6 & 47.46 & 45.06 & 41.60 & 38.08 & 36.02 & 34.85 & 25.29 & 14.59 \\
7 & 44.55 & 40.98 & 38.32 & 33.25 & 30.97 & 29.48 & 19.37 & 10.86 \\
8 & 45.63 & 45.15 & 44.21 & 43.46 & 42.71 & 42.30 & 37.02 & 26.50 \\
9 & 51.01 & 47.71 & 42.76 & 37.37 & 33.58 & 30.55 & 23.27 & 20.84 \\
10 & 54.43 & 52.41 & 47.81 & 41.39 & 38.38 & 35.18 & 26.08 & 14.02 \\
11 & 52.16 & 43.94 & 39.52 & 37.90 & 37.27 & 36.78 & 29.09 & 25.69 \\
\hline
\end{tabular}

The functions used to describe water retention properties are the following: the van Genuchten (1980) water retention equation, as in

$\frac{\theta-\theta_{\mathrm{r}}}{\theta_{\mathrm{s}}-\theta_{\mathrm{r}}}=\frac{1}{\left[1+(\alpha h)^{n}\right]^{m}}$

and the Brooks and Corey (1964) equation:

$\frac{\theta-\theta_{\mathrm{r}}}{\phi-\theta_{\mathrm{r}}}=\left\{\begin{array}{l}\left(\frac{h}{h_{b}}\right)^{\lambda}, \quad h>h_{b} \\ 1, \quad h \leq h_{b},\end{array}\right.$

where $\theta$ is the volumetric soil water content $\left(\mathrm{cm}^{3} \mathrm{~cm}^{-3}\right) ; \theta_{\mathrm{r}}$ is the residual soil water content $\left(\mathrm{cm}^{3} \mathrm{~cm}^{-3}\right) ; \theta_{\mathrm{s}}$ is the saturated soil water content, $\left(\mathrm{cm}^{3} \mathrm{~cm}^{-3}\right) ; \phi$ is the soil porosity, $\left(\mathrm{cm}^{3} \mathrm{~cm}^{-3}\right) ; \lambda$ is the pore size distribution index (dimensionless); $h$ is the capillary pressure $(\mathrm{cm}) ; h_{b}$ is the air-entry pressure $(\mathrm{cm}) ; \alpha$ is the parameter of the van Genuchten equation, corresponding approximately to the inverse of the air-entry value, $\left(\mathrm{cm}^{-1}\right) ; m, n$ are the empirical shape-defining parameters in the van Genuchten equation, (dimensionless).

The values of the parameters $\left(\theta, \theta_{\mathrm{r}}, \theta_{\mathrm{s}}, \phi, \lambda, h_{b}, \alpha, m, n\right)$ are predicted by PTFs, which are developed from the measured data set (Wösten et al., 2001).

In this study the processing of the PTFs was performed using the program CalcPTF 3.0 (Guber and Pachepsky, 2010). This contains a class of PTFs generated from the HYPRES database; see Table 3.

CalcPTF 3.0 is a computer program developed to calculate PTFs in order to estimate parameters of the Brooks and Corey model and the van Genuchten model. The inputs used in this program are: soil texture, organic carbon content, bulk density and particle density.

The database HYPRES (Hydraulic Properties of European Solis; Wösten et al., 1999) draws together some basic soil information and soil hydraulic data from which PTFs applicable to Europe can be derived (Nemes et 
Table 3. Authors and localization of database and model used for the different PTFs. Legend: VG represents van Genuchten, BC represents Brooks-Corey.

\begin{tabular}{lll}
\hline PTF & Region & Model \\
\hline HYPRES & Europe & VG \\
Saxton et al. (1986) & USA, nationwide & BC \\
Campbell and Shiosawa (1992) & None particular & BC \\
Rawls and Brakensiek (1985) & USA, nationwide & BC \\
Williams et al. (1992) & Australia & BC \\
Williams et al. (1992) & Australia & BC \\
Oosterveld and Chang (1980) & Canada, Alberta & BC \\
Mayr and Jarvice (1999) & UK & BC \\
Wösten et al. (1999) & Europe & VG \\
Varallyay et al. (1982) & Hungary & VG \\
Vereecken et al. (1989) & Belgium & VG \\
Wösten et al. (1999) & Europe & VG \\
Tomasella and Hodnett (1998) & Brazil & VG \\
Rawls et al. (1982b) & USA, nationwide & VG \\
(corrected for OM according & & \\
to Nemes et al., 2009) & & \\
Gupta and Larson (1979) & Central USA & VG \\
Rajkai and Varallyay (1992) & Hungary & VG \\
Rawls et al. (1983) & USA, nationwide & VG \\
(corrected for OM according to & & \\
Nemes et al., 2009) & & \\
\hline
\end{tabular}

al., 2001b). Using the HYPRES database, two different sets of PTFs were derived: class pedotransfer functions and continuous pedotransfer functions. Class PTFs predict the hydraulic characteristics for each of the five texture classes (coarse: clay $<18 \%$ and sand $>65 \%$, $18 \%<$ clay $<35 \%$ and $15 \%<$ sand; medium: clay $<18 \%$ and $15 \%<$ sand $<65 \%$; medium fine: clay $<35 \%$ and sand $<15 \%$; fine: $35 \%<$ clay $<60 \%$; very fine: $60 \%<$ clay) and for two pedological classes within them (topsoils and subsoils) plus an additional class which encompassed the organic soil horizons. Continuous pedotransfer functions can predict hydraulic properties from individual measurements of soil texture, organic carbon content and bulk density.

The goodness of the PTFs and their ability to describe the hydraulic characteristics of the landfill coverage soils was calculated through the root mean square error (RMSE) test based on the difference between the values of volumetric content of water at different suction values, measured and estimated, starting from the following equation:

RMSE $=\sqrt{\frac{1}{N} \sum_{i=1}^{N}\left(\theta_{i}-\theta_{i}^{*}\right)^{2}}$,

where $N$ is the number of measurements; $\theta i$ and $\theta i *$ is the volumetric water content $(\theta \%)$, measured and estimated.

The hydraulic data of the landfill cover soils obtained instrumentally and through PTFs were also compared with those of a reference soil. The reference soil chemical- physical properties are chosen to describe a non-degraded natural soil with the same texture, i.e. silt loam, with a bulk and particle density of respectively 1.3 and $2.3 \mathrm{~g} \mathrm{~cm}^{-3}$ of landfill soils but with an average organic carbon content of $1 \%$, which is typical of Piacenza natural soils, well structured and with a depth of $1 \mathrm{~m}$. The volumetric water content of the reference soil at different suction values was calculated through the arithmetic mean of the water contents from the 17 PTFs, so it is possible to achieve an estimate of available water content.

\subsection{Flora and vegetation}

The vegetation data were collected by making up 52 phytosociological relevés using the Zurich-Montpellier school method (Braun-Blanquet, 1964). The sampling sites were selected to summarize the vegetation of the whole area. Each relevé included an area of $16 \mathrm{~m}^{2}(4 \mathrm{~m} \times 4 \mathrm{~m})$ and was georeferenced. For each sampling site, the plant species present were listed and their cover was estimated using the values of the Braun-Blanquet conventional scale $(r=$ sporadic species; $+=<1 \%, 1=1-5 \%, 2=5-25 \%, 3=25-50 \%$, $4=50-75 \%, 5=75-100 \%$ ). The relevés were periodically monitored from April to September 2012.

Pignatti (1982) was consulted for the identification of the species, while the specific nomenclature is according to Conti et al. (2005). In order to process the biological spectrum of the plant list, the data concerning the biological form according to Raunkiaer (1934) (therophytes - T: annual herbs; hemicryptophytes - H: perennial herbs; geophytes - G: perennial herbs with underground storage organs; chamaephytes $-\mathrm{Ch}$ : woody plants with buds at no more than $25 \mathrm{~cm}$ above the soil surface; phanerophytes $-\mathrm{P}$ : trees and shrubs with buds over $25 \mathrm{~cm}$ above the soil surface) were taken from Romani and Alessandrini (2001).

Landolt's $F$ index (soil moisture) (Landolt, 1977), updated by Landolt et al. (2010), provides a guide on the need of water by plant species during their growth period. The $F$ values range from 1 to 5 ( 1 is very dry, 1.5 is dry, 2 is moderately dry, 2.5 is fresh, 3 is moderately moist, 3.5 is moist, 4 is very moist, 4.5 is wet and 5 is flooded or submerged) and were attributed to all the species, recorded in order, to obtain information on the degree of humidity of the landfill soil cover. To each species was also assigned its respective life strategy according to Grime $(2001,1979)$ ( $c$ describes competitive strategists, $r$ describes ruderal strategists and $s$ describes stress-tolerant strategists); this information was retrieved from Landolt et al. (2010), according to the adjustments proposed by the author. Starting from the climate, soil and vegetation data, reference crop evapotranspiration (ETo), the total available moisture (TAM) and the readily available moisture (RAM) were calculated using the CropWat 8.0 software $\left({ }^{\odot}\right.$ FAO 2009) according to Allen et al. (1998) and Doorenbos and Kassam (1979). 


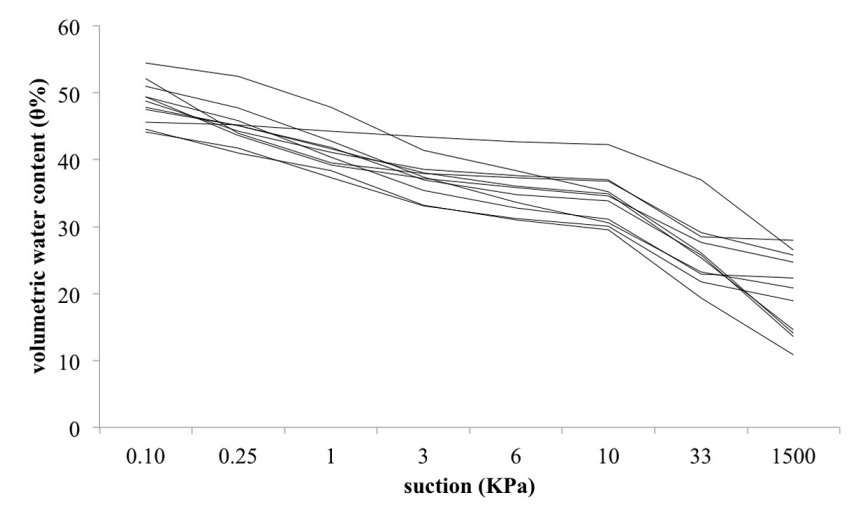

Figure 1. Water retention curves of sampled soils.

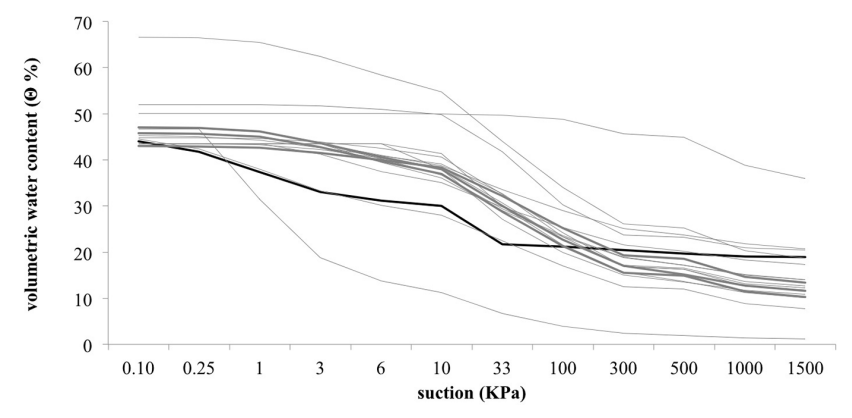

Figure 2. Sample 5: actual (black) and PTF water retention curves; the curves by Wösten et al. 1999 are highlighted.

\section{Results}

\subsection{Soil}

By the measurement of volumetric water content, it is possible to describe the water retention curve for all of the samples. Table 2 shows the measured volumetric water contents at the different suction values investigated and Fig. 1 shows their water retention curves. The water retention curves, with the exception of sample 8 , display a similar trend. For suction values less than $10 \mathrm{kPa}$, the values are not very different, while in the end part - when the suction is high - there are some differences. The curve's slope increases from 10 to $33 \mathrm{kPa}$ due to the different water extractor used - a sand box for $10 \mathrm{kPa}$ and a Richards plate for $33 \mathrm{kPa}$.

As one of the study aims is to compare the landfill soil with a natural reference soil, in the first part of the paper, sample 5 is analysed. Sample 5 is the only landfill soil showing the same amount of organic carbon as the reference one.

Using sample 5 chemical-physical data as inputs of PTFs, the sample 5 predictive water retention curve is compared with the measured one. This comparison is shown in Fig. 2; in this Figure, the curves by Wösten et al. (1999)(PTFs applicable to Europe soils) are highlighted. From the comparison it clearly emerges that for suction values lower than $100 \mathrm{kPa}$, all PTFs except one overestimate the measured data, whereas for suction values of $1500 \mathrm{kPa}$ for 12 cases the measured value is higher than the predicted one.

To identify which of the authors, and thus of the models, are more accurate in describing the hydraulic behaviour of the landfill soils, samples of chemical-physical data are used as inputs of PTFs, so all water retention curves are developed and then the RMSE test was conducted (Fig. 3, Table 4). It emerges that the curve by Wösten al. (1999), showing a continuous pedotransfer function, is the closest to the measured data. The results of this test and the comparisons indicate a need to conduct studies to develop new parameter values which are able to describe the behaviour of degraded soils.

To compare natural soils with a reference one, reference soil water retention curves were developed using the PTFs. The reference soil water retention curve is described as the arithmetic mean of volumetric water content at different suction values obtained from processing PTFs. The sample 5 water retention curve is compared with the reference one (Fig. 4). This comparison reveals that the reference soil PTFs data always overestimate the measured data for all suction values lower than $100 \mathrm{kPa}$, whereas for suction values higher than $300 \mathrm{kPa}$, measured data are greater than the reference soil.

To compare the measured hydraulic properties of the landfill soil with the reference soil, their volumetric water contents - at suctions $0.10 \mathrm{kPa}$, at field capacity, at wilting point and the available water for plants - are compared. The histogram in Fig. 5 shows the water content at a suction of $0.10 \mathrm{kPa}$; soils have values similar to each other (average $\theta \%$ is $48.61 \%$, SD $3.18 \%$ ), and also similar to the reference soil $(\theta \%$ is $46.32 \%)$.

The field capacity is described as the optimal relationship between water and air in the soil; this condition is verified when the micropore volume is entirely occupied by water while macropore volume is entirely occupied by air. In the literature the field capacity is represented by the water content at suction values in the range of $10 \mathrm{kPa}$ and $33 \mathrm{kPa}(10 \mathrm{kPa}$ for sandy soil and $33 \mathrm{kPa}$ for other soils). At field capacity (histogram Fig. 6), the sample soil average $\theta \%$ is 26.05 , $\mathrm{SD} 4.68 \%$; this value is lower than that of the reference soil $(\theta \%$ is $30.16 \%)$.

The histogram in Fig. 7 shows the soils at a suction of $1500 \mathrm{kPa}$ (wilting point); the average of volumetric water content of soils sampled is $\theta \%$ is $19.98 \%$, SD $5.97 \%$; the trend in this case is very variable, with one soil that has a water content of $\theta \%=27.91 \%$ and another $\theta \%$ is $10.86 \%$. The reference soil instead has a value of $\theta \%$ is $13.66 \%$; in nine soils the water content is higher than that of the reference soil.

In general terms, the available water for plants is defined as the difference between soil water content at suction $33 \mathrm{kPa}-$ soil water content at field capacity - and $1500 \mathrm{kPa}$ - soil water content at wilting point (histogram Fig. 8). For the investigated soils the average amount of available water has a value of $\theta \%=6.06 \%$, very high $\mathrm{SD} 4.70 \%$, with a minimum 


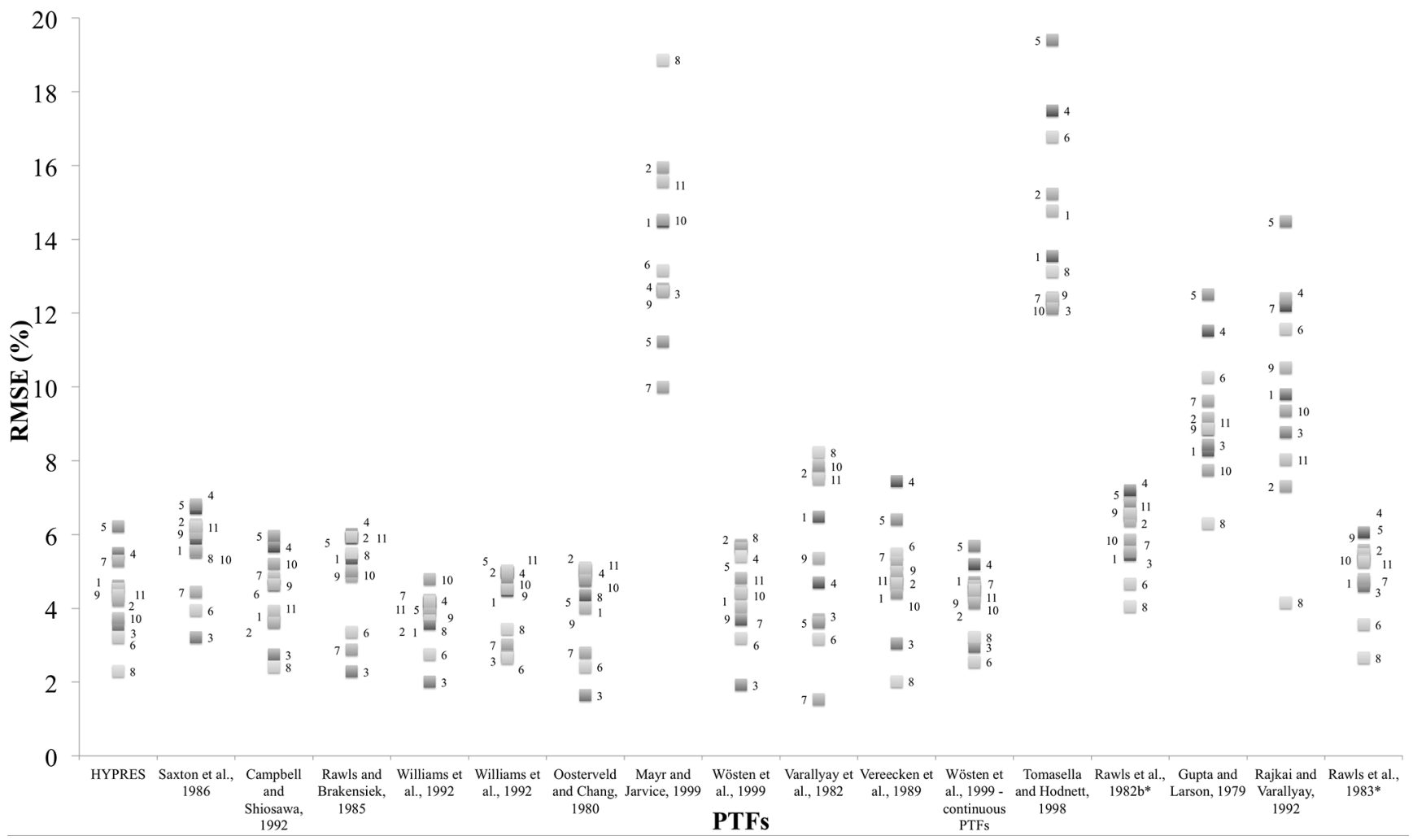

Figure 3. Matrix representing the result of the RMSE test - each pixel for a combination of the soil's PTF and RMSE.

Table 4. Results of the calculation of RMSE.

\begin{tabular}{lrrrrrrrrrrr}
\hline PTF & \multicolumn{10}{c}{ RMSE \% (for samples) } \\
\cline { 2 - 11 } & 1 & 2 & 3 & 4 & 5 & 6 & 7 & 8 & 9 & 10 & 11 \\
\hline HYPRES & 4.6 & 4.2 & 3.6 & 5.5 & 6.2 & 3.2 & 5.3 & 2.3 & 4.5 & 3.7 & 4.4 \\
Saxton et al. (1986) & 5.9 & 6.3 & 3.2 & 6.7 & 6.8 & 4.0 & 4.5 & 5.6 & 6.0 & 5.6 & 6.2 \\
Campbell and Shiosawa (1992) & 3.7 & 3.6 & 2.8 & 5.7 & 6.0 & 4.6 & 4.8 & 2.4 & 4.7 & 5.2 & 3.9 \\
Rawls and Brakensiek (1985) & 5.4 & 5.9 & 2.3 & 6.0 & 5.9 & 3.4 & 2.9 & 5.5 & 4.9 & 5.0 & 5.9 \\
Williams et al. (1992) & 3.6 & 4.0 & 2.0 & 4.2 & 4.2 & 2.8 & 4.2 & 3.8 & 4.0 & 4.8 & 4.2 \\
Williams et al. (1992) & 4.5 & 5.0 & 2.7 & 5.0 & 5.0 & 2.7 & 3.0 & 3.5 & 4.5 & 4.8 & 5.0 \\
Oosterveld and Chang (1980) & 4.4 & 5.1 & 1.7 & 5.0 & 4.8 & 2.4 & 2.8 & 4.9 & 4.0 & 4.8 & 5.1 \\
Mayr and Jarvice (1999) & 14.5 & 16.0 & 12.7 & 12.6 & 11.2 & 13.2 & 10.0 & 18.9 & 12.6 & 14.5 & 15.6 \\
Wösten et al. (1999) & 3.7 & 5.7 & 1.9 & 5.7 & 5.6 & 3.2 & 4.5 & 5.4 & 4.0 & 4.8 & 4.4 \\
Varallyay et al. (1982) & 6.5 & 7.7 & 3.7 & 4.7 & 3.6 & 3.2 & 1.5 & 8.2 & 5.4 & 7.9 & 7.5 \\
Vereecken et al. (1989) & 4.8 & 4.7 & 3.1 & 7.5 & 6.4 & 5.5 & 5.2 & 2.0 & 5.0 & 4.4 & 4.7 \\
Wösten et al. (1999) & 4.7 & 4.3 & 3.0 & 5.2 & 5.7 & 2.6 & 4.6 & 3.2 & 4.5 & 4.2 & 4.5 \\
Tomasella and Hodnett (1998) & 13.6 & 15.2 & 12.2 & 17.5 & 19.4 & 16.8 & 12.4 & 13.1 & 12.4 & 12.1 & 14.8 \\
Rawls et al. (1982b)* & 5.5 & 7.1 & 6.5 & 7.2 & 6.8 & 4.7 & 5.9 & 4.1 & 6.4 & 5.5 & 6.6 \\
Gupta and Larson (1979) & 8.3 & 9.2 & 8.4 & 11.5 & 12.5 & 10.3 & 9.6 & 6.3 & 8.9 & 7.8 & 8.9 \\
Rajkai and Varallyay (1992) & 9.8 & 7.3 & 8.8 & 12.2 & 14.5 & 11.6 & 12.4 & 4.2 & 10.5 & 9.4 & 8.0 \\
Rawls et al. (1983)* & 4.7 & 5.4 & 4.6 & 6.1 & 5.6 & 3.6 & 4.8 & 2.7 & 5.5 & 5.3 & 5.3 \\
\hline
\end{tabular}

* corrected for OM according to Nemes et al. (2009).

value of $\theta \%=0.55 \%$ and a maximum of $\theta \%=12.14 \%$; the reference soil has a value of $\theta \%=16.50 \%$.

All the sampled soils have a much lower available water $\theta \%$ than the reference soil, despite having an organic carbon content about twice as high as in the reference soil. Generally, high values of organic carbon correspond to high levels of organic matter, which enhances permeability and water availability in the soil. It would be interesting to study 


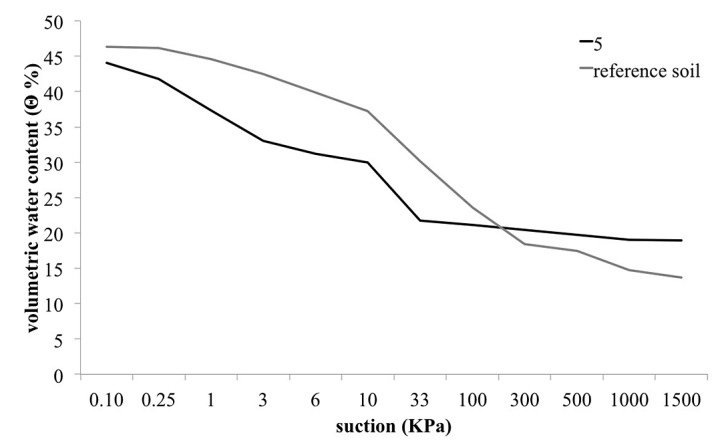

Figure 4. Comparison between sample 5 water retention curve and the reference curve - described as the arithmetic mean of PTFs values.

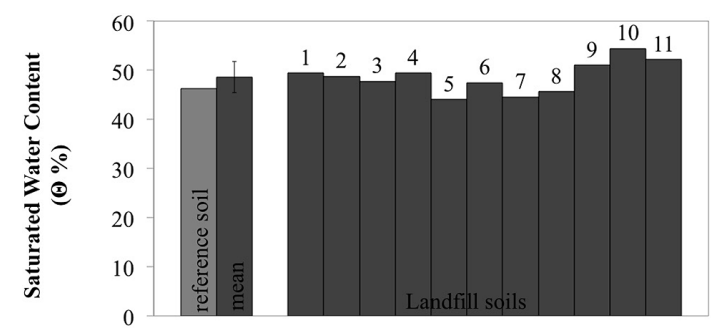

Figure 5. Volumetric water content $(\theta \%)$ at suction $0.10 \mathrm{kPa}$ : comparison between reference soil and landfill soils.

why a soil presenting characters of physical degradation i.e. compaction, associated with a lack of organic carbon content, has, on the contrary, a high organic carbon content. With this in mind, it would be interesting, also, to study the carbon decomposition in humic and fulvic acids in association with limestone content.

\subsection{Flora and vegetation}

The total number of plant species sampled amounts to 90 (see Appendix A); almost all of them are very common and abundant in the province of Piacenza (Bracchi and Romani, 2010; Romani and Alessandrini, 2001). Most of the species were found to be competitive-ruderal $(43 \%)$ and ruderal (13\%) (Grime, 2001) and belonging to the phytosociological class Stellarietea mediae R. Tx. Lohm. et PRSG. in Tx. 1950 which includes nitrophilous annual vegetation (Mucina et al., 1993; Oberdorfer, 1993; Ubaldi, 2008).

Table 5 shows a list of the flora biological spectrum. The study area has a particularly high percentage of therophytes $(45 \%)$ when compared to the values of the biological range of the province of Piacenza (23\%; Romani and Alessandrini, 2001) and Emilia-Romagna (28\%; Pignatti et al., 2001). Typically, ephemeral annual species tend to be concentrated in urban environments (Sukopp and Werner, 1983) and in Italy, regardless of human disturbance, their percentage increases gradually from north to south in response

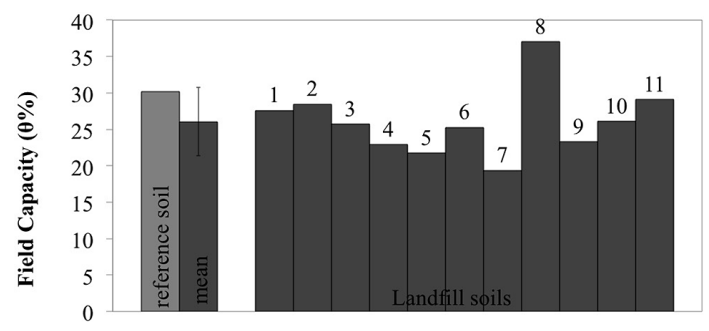

Figure 6. Volumetric water content $(\theta \%)$ at field capacity: comparison between reference soil and landfill soils.

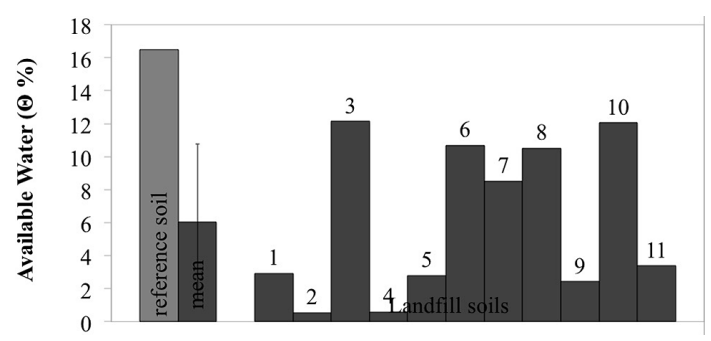

Figure 7. Volumetric water content $(\theta \%)$ at a suction of $1500 \mathrm{kPa}$ : comparison between reference soil and landfill soils.

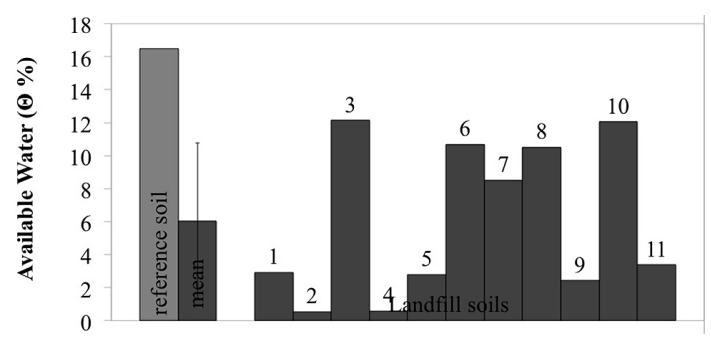

Figure 8. Available water to plants $(\theta \%)$ : comparison between reference soil and landfill soils.

to the emergence of a distinctly arid climate (Pignatti, 1994, 1976).

Fig. 9 represents the monthly rainfall and evapotranspiration and it should be noted that the ETo is greater than the rainfall in the period from May to August, indicating a summer drought.

The histogram referring to the $F$ index (Fig. 10) shows that most of the species found require soils with a moisture content ranging from moderately dry to moderately moist. The typically xerophyte species and those found in submerged soils are absent, while there are two (Bolboschoenus maritimus (L.) Palla and Eleocharis palustris (L.) Roem. \& Schult) that need wet soil.

In Fig. 11 the graphs referring to the amount of water lost from a common agricultural soil of medium texture $1 \mathrm{~m}$ deep (a), and the soil cover of the landfill (b) are presented, considering both the climatic conditions of Piacenza and the cover of grassland vegetation of perennial grasses (cool season grass varieties including bluegrass, fescue and ryegrass; 
Table 5. Biological spectrum of flora.

\begin{tabular}{lc}
\hline & Biological spectrum of flora $(\%)$ \\
\hline Therophytes & 45 \\
Hemicryptophytes & 41 \\
Geophytes & 11 \\
Phanerophytes & 3 \\
\hline
\end{tabular}

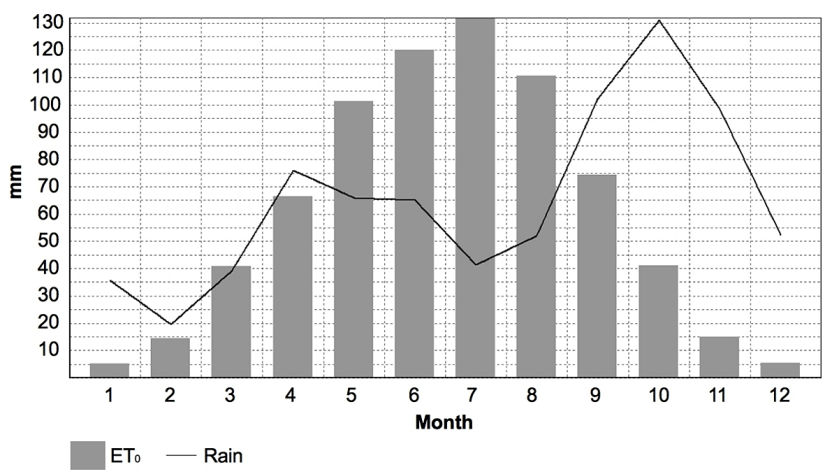

Figure 9. Monthly rainfall and evapotranspiration (ETo). Climate data source: San Lazzaro Alberoni weather station (Piacenza 19612005).

Allen et al., 1998). The soil of the landfill has less water available to vegetation compared to agricultural soil.

\section{Discussion and conclusions}

In this study, the attempt to relate the hydraulic properties of degraded soil with plant coverage is presented.

The hydrological properties of a degraded soil are described through a comparison between the laboratory tests and the results of predictive systems by PTFs, showing that the PTFs are not able to describe them.

The study of the hydraulic properties of landfill cover soils has outlined that these soils have less water content available in comparison with a natural reference soil; this is a characteristic of degradation.

On the basis of PTFs, some conclusions can be formulated. PTFs have the advantage of being relatively inexpensive and easy to derive and use, but for application at a specific point and for soils that are outside the range of soils used to derive them, prediction using PTFs might be inadequate. In this case, direct measurement is the only option (Wösten et al., 2001) and it can be interesting to conduct studies to develop degraded soils using new PTFs parameters and to relate them to the type of soil organic content. Generally, high values of soil organic carbon correspond to high levels of organic matter, which enhances permeability and water availability. With this in mind, it would be interesting to study why a soil presenting characters of physical degradation i.e. compaction, associated with a lack of organic carbon content, has, on the

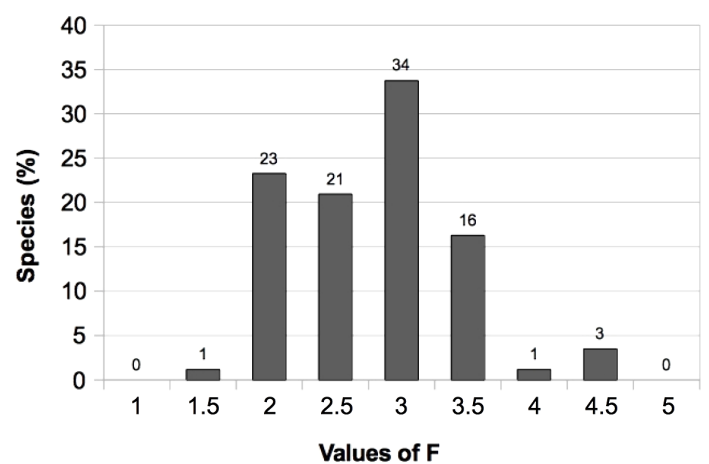

Figure 10. $F$ index (soil moisture). Percentages are weighted by the frequency of the species in the monitoring sites (see column "Presence" in the Appendix). Legend: 1 is very dry, 1.5 is dry, 2 is moderately dry, 2.5 is fresh, 3 is moderately moist, 3.5 is moist, 4 is very moist, 4.5 is wet and 5 is flooded or submerged.

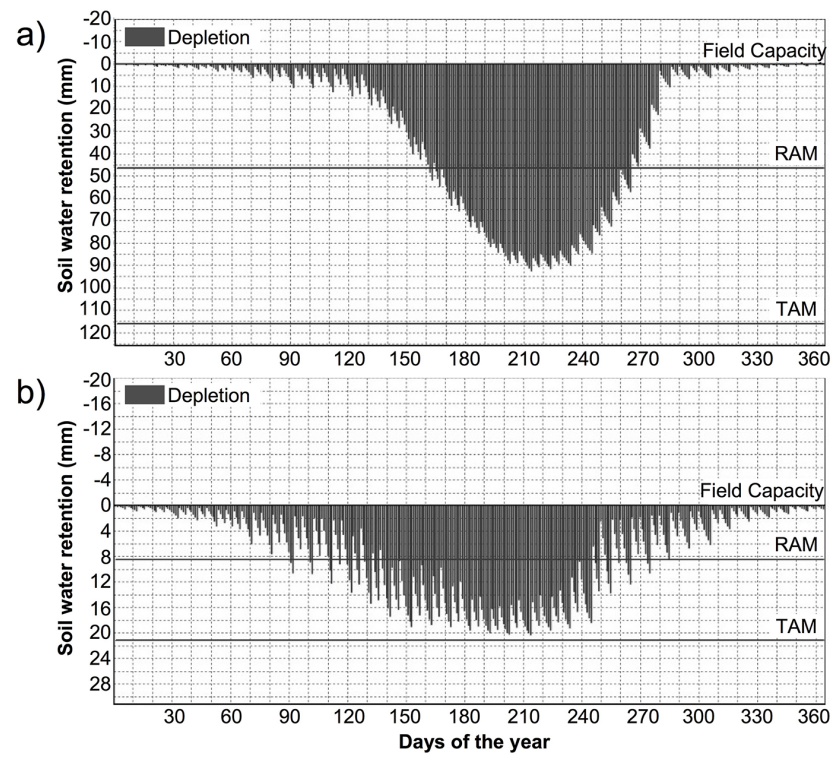

Figure 11. Water lost from agricultural soil (a) and from the landfill cover soil (b) by Crop Wat 8.0 software. Legend: RAM represents readily available moisture; TAM represents total available moisture.

contrary, a high organic carbon content. It would be interesting, also, to study the carbon decomposition in humic and fulvic acids in association with limestone content.

Analysing vegetation, it can be said that the landfill vegetation is mainly related to the soil character. The low water content, together with the lack of depth and compacted structure, would justify the current presence of a vegetation cover which consists predominantly of therophytes instead of a more developed and stable perennial vegetation with shrubs and trees, as observed for other landfills several years after their coverage (El-Sheikh et al., 2012; Huber-Humer and Klug-Pümpel, 2004; Rebele and Lehmann, 2002). The high frequency of therophyte does not seem to be justified by 
summer drought and by the low level of human disturbance that affected the area in recent years, given that, under the same climatic conditions, the potential vegetation of the area should be represented by riparian forests of Populetalia albae Br.-Bl. 1935 (Puppi et al., 2010). These forests, although not very widespread, are present and contiguous to the landfill.

The presence of Bolboschoenus maritimus (L.) and Eleocharis palustris (L.), which need wet soil, is explained by the fact that $F$ refers to soil water availability during the time of year when the species carry out their vegetative cycle (Landolt et al., 2010). In this case the above-mentioned hydrophilic plants were detected only in the spring months when the monthly evapotranspiration is less than or equal to rainfall.

In comparison with agricultural soil in the same climatic conditions, the landfill soil has less water available to vegetation, and this contributes to water stress for plants over a longer period (March to September) and is more pronounced as the amount of water absorbed by plants during the summer is close to their permanent wilting point (TAM line).
The low water content in association with high organic carbon, the lack of depth, the compacted structure of these soils and the current presence of a vegetation cover, which consists predominantly of therophytes, are important studied aspects of the aims of the New Life project, which seeks to establish a treatment for restoring degraded soils. This treatment - the reconstitution - produces a new soil, called reconstituted soil. The comparison between chemicalphysical characters of degraded and reconstituted soil is very important. In this comparison it will be interesting to study their hydraulic properties in relation to their plant coverage.

Edited by: A. Cerdà 


\section{Appendix A}

Table A1. Species, life form, $F$ index, plant strategies and presence of the sampled plant.

\begin{tabular}{|c|c|c|c|c|c|}
\hline$n$ & Species & Life form & $F$ index & Plant strategy & Presence \\
\hline 1 & Abutilon theophrasti Medik. & $\mathrm{T}$ & 2.5 & $\mathrm{cr}$ & $3 / 52$ \\
\hline 2 & Agrimonia eupatoria $\mathrm{L}$. & $\mathrm{T}$ & 2 & $\mathrm{cr}$ & $2 / 52$ \\
\hline 3 & Allium spp. & - & - & - & $1 / 52$ \\
\hline 4 & Alopecurus myosuroides Huds. & $\mathrm{T}$ & 3 & $\mathrm{r}$ & $10 / 52$ \\
\hline 5 & Alopecurus pratensis L. & $\mathrm{T}$ & 3.5 & $\mathrm{cs}$ & $5 / 52$ \\
\hline 6 & Alopecurus rendlei Eig & $\mathrm{T}$ & 3 & crs & $7 / 52$ \\
\hline 7 & Amaranthus retroflexus $\mathrm{L}$. & $\mathrm{T}$ & 2.5 & $\mathrm{cr}$ & $18 / 52$ \\
\hline 8 & Ambrosia artemisiifolia $\mathrm{L}$. & $\mathrm{T}$ & 2 & $\mathrm{cr}$ & $15 / 52$ \\
\hline 9 & Amorpha fruticosa $\mathrm{L}$. & $\mathrm{H}$ & 3.5 & crs & $1 / 52$ \\
\hline 10 & Aristolochia clematitis $\mathrm{L}$. & G & 3.5 & $\mathrm{cr}$ & $2 / 52$ \\
\hline 11 & Arrhenatherum elatius (L.) P. Beauv. ex J. and C. Presl & $\mathrm{H}$ & 3 & $\mathrm{cr}$ & $21 / 52$ \\
\hline 12 & Artemisia vulgaris $\mathrm{L}$. & $\mathrm{G}$ & 2.5 & crs & $13 / 52$ \\
\hline 13 & Atriplex patula $\mathrm{L}$. & $\mathrm{T}$ & 2.5 & $\mathrm{cr}$ & $10 / 52$ \\
\hline 14 & Avena fatua $\mathrm{L}$. & $\mathrm{T}$ & 2.5 & $\mathrm{cr}$ & $14 / 52$ \\
\hline 15 & Ballota nigra $\mathrm{L}$ & $\mathrm{T}$ & 2.5 & $\mathrm{cr}$ & $4 / 52$ \\
\hline 16 & Bolboschoenus maritimus (L.) Palla & $\mathrm{T}$ & 4.5 & $\mathrm{cs}$ & $1 / 52$ \\
\hline 17 & Bromus hordeaceus L. & $\mathrm{T}$ & 3 & $\mathrm{cr}$ & $14 / 52$ \\
\hline 18 & Bromus sterilis L. & $\mathrm{T}$ & 2 & $\mathrm{r}$ & $30 / 52$ \\
\hline 19 & Capsella bursa-pastoris (L.) Medik. & $\mathrm{T}$ & 2 & $\mathrm{r}$ & $6 / 52$ \\
\hline 20 & Cardamine hirsuta $\mathrm{L}$. & $\mathrm{T}$ & 3 & rs & $3 / 52$ \\
\hline 21 & Cerastium spp. & - & - & - & $9 / 52$ \\
\hline 22 & Chenopodium album $\mathrm{L}$. & $\mathrm{T}$ & 2 & $\mathrm{r}$ & $27 / 52$ \\
\hline 23 & Cichorium intybus $\mathrm{L}$. & $\mathrm{T}$ & 2.5 & crs & $2 / 52$ \\
\hline 24 & Cirsium arvense (L.) Scop. & $\mathrm{T}$ & 3 & $\mathrm{cr}$ & $6 / 52$ \\
\hline 25 & Cirsium vulgare (Savi) Ten. & $\mathrm{T}$ & 3 & $\mathrm{cr}$ & $1 / 52$ \\
\hline 26 & Convolvulus arvensis $\mathrm{L}$. & $\mathrm{T}$ & 2.5 & $\mathrm{cr}$ & $50 / 52$ \\
\hline 27 & Crepis setosa Haller f. & $\mathrm{H}$ & 1.5 & $\mathrm{r}$ & $5 / 52$ \\
\hline 28 & Crepis vesicaria $\mathrm{L}$. & $\mathrm{T}$ & 2 & $\mathrm{cr}$ & $2 / 52$ \\
\hline 29 & Cynodon dactylon (L.) Pers. & $\mathrm{T}$ & 2 & $\mathrm{cs}$ & $44 / 52$ \\
\hline 30 & Dactylis glomerata L. & $\mathrm{H}$ & 3 & crs & $6 / 52$ \\
\hline 31 & Dipsacus fullonum L. & $\mathrm{T}$ & 3.5 & $\mathrm{cr}$ & $1 / 52$ \\
\hline 32 & Echinochloa crusgalli (L.) P. Beauv. & $\mathrm{G}$ & 3.5 & $\mathrm{cr}$ & $3 / 52$ \\
\hline 33 & Eleocharis palustris (L.) Roem. and Schult. & $\mathrm{H}$ & 4.5 & crs & $2 / 52$ \\
\hline 34 & Elymus repens (L.) Gould & $\mathrm{T}$ & 3 & cs & $52 / 52$ \\
\hline 35 & Erigeron annuus (L.) Desf. & $\mathrm{H}$ & 2.5 & $\mathrm{cr}$ & $2 / 52$ \\
\hline 36 & Euphorbia cyparissias L. & $\mathrm{H}$ & 2 & crs & $1 / 52$ \\
\hline 37 & Galium aparine $\mathrm{L}$. & G & 3 & $\mathrm{cr}$ & $8 / 52$ \\
\hline 38 & Galium verum $\mathrm{L}$. & $\mathrm{H}$ & 2.5 & crs & $2 / 52$ \\
\hline 39 & Geranium dissectum $\mathrm{L}$. & $\mathrm{T}$ & 3 & $\mathrm{cr}$ & $17 / 52$ \\
\hline 40 & Geranium molle L. & $\mathrm{H}$ & 2.5 & $\mathrm{cr}$ & $9 / 52$ \\
\hline 41 & Hordeum murinum $\mathrm{L}$. & $\mathrm{T}$ & 2 & $\mathrm{r}$ & $23 / 52$ \\
\hline 42 & Humulus japonicus Siebold and Zucc. & $\mathrm{T}$ & 3.5 & $\mathrm{cr}$ & $1 / 52$ \\
\hline 43 & Hypericum perforatum $\mathrm{L}$. & G & 3 & crs & $2 / 52$ \\
\hline 44 & Lactuca serriola $\mathrm{L}$. & $\mathrm{H}$ & 2 & $\mathrm{cr}$ & $9 / 52$ \\
\hline 45 & Lamium purpureum $\mathrm{L}$. & $\mathrm{T}$ & 3 & $\mathrm{r}$ & $7 / 52$ \\
\hline 46 & Lapsana communis $\mathrm{L}$. & $\mathrm{T}$ & 3.5 & $\mathrm{cr}$ & $2 / 52$ \\
\hline 47 & Lepidium draba $\mathrm{L}$. & G & 2 & $\mathrm{cr}$ & $3 / 52$ \\
\hline 48 & Lolium perenne $\mathrm{L}$. & $\mathrm{H}$ & 3 & $\mathrm{cr}$ & $4 / 52$ \\
\hline 49 & Lythrum salicaria L. & $\mathrm{T}$ & 4 & $\mathrm{cs}$ & $1 / 52$ \\
\hline 50 & Malva alcea $\mathrm{L}$. & $\mathrm{T}$ & 2.5 & cs & $2 / 52$ \\
\hline
\end{tabular}


Table A1. Continued.

\begin{tabular}{|c|c|c|c|c|c|}
\hline$n$ & Species & Life form & $F$ index & Plant strategy & Presence \\
\hline 51 & Malva sylvestris $\mathrm{L}$. & $\mathrm{T}$ & 2.5 & crs & $2 / 52$ \\
\hline 52 & Matricaria chamomilla L. & $\mathrm{H}$ & 3 & $\mathrm{r}$ & $2 / 52$ \\
\hline 53 & Medicago lupulina $\mathrm{L}$. & $\mathrm{T}$ & 2 & rs & $3 / 52$ \\
\hline 54 & Medicago sativa $\mathrm{L}$. & $\mathrm{H}$ & 2 & cs & $8 / 52$ \\
\hline 55 & Melilotus albus Medik. & $\mathrm{H}$ & 2.5 & $\mathrm{cr}$ & $3 / 52$ \\
\hline 56 & Mentha arvensis $\mathrm{L}$. & $\mathrm{H}$ & 3.5 & crs & $2 / 52$ \\
\hline 57 & Myosotis arvensis (L.) Hill & $\mathrm{T}$ & 2 & $\mathrm{cr}$ & $2 / 52$ \\
\hline 58 & Onopordum acanthium $\mathrm{L}$. & $\mathrm{T}$ & 2 & $\mathrm{cr}$ & $2 / 52$ \\
\hline 59 & Ornithogalum umbellatum L. & $\mathrm{H}$ & 3 & crs & $1 / 52$ \\
\hline 60 & Papaver rhoeas L. & $\mathrm{H}$ & 2 & $\mathrm{r}$ & $1 / 52$ \\
\hline 61 & Persicaria lapathifolia (L.) Delarbre & $\mathrm{H}$ & 2.5 & $\mathrm{cr}$ & $2 / 52$ \\
\hline 62 & Plantago lanceolata $\mathrm{L}$ & $\mathrm{H}$ & 3.5 & crs & $8 / 52$ \\
\hline 63 & Poa pratensis L. & $\mathrm{T}$ & 3.3 & crs & $1 / 52$ \\
\hline 64 & Poa trivialis $\mathrm{L}$. & $\mathrm{H}$ & 3.5 & crs & $14 / 52$ \\
\hline 65 & Polygonum aviculare $\mathrm{L}$. & $\mathrm{T}$ & 3.5 & $\mathrm{r}$ & $23 / 52$ \\
\hline 66 & Portulaca oleracea L. & $\mathrm{H}$ & 2.5 & $\mathrm{r}$ & $1 / 52$ \\
\hline 67 & Potentilla reptans $\mathrm{L}$. & $\mathrm{H}$ & 3 & crs & $3 / 52$ \\
\hline 68 & Ranunculus bulbosus L. & $\mathrm{H}$ & 2 & crs & $10 / 52$ \\
\hline 69 & Robinia pseudoacacia L. & $\mathrm{H}$ & 2.5 & $\mathrm{c}$ & $1 / 52$ \\
\hline 70 & Rumex crispus $\mathrm{L}$. & $\mathrm{H}$ & 3.5 & $\mathrm{cr}$ & $44 / 52$ \\
\hline 71 & Rumex pulcher $\mathrm{L}$. & $\mathrm{H}$ & 3 & crs & $5 / 52$ \\
\hline 72 & Salix alba $\mathrm{L}$. & $\mathrm{T}$ & 4.5 & $\mathrm{c}$ & $1 / 52$ \\
\hline 73 & Salvia pratensis $\mathrm{L}$. & $\mathrm{H}$ & 2 & crs & $2 / 52$ \\
\hline 74 & Solanum nigrum L. & $\mathrm{G}$ & 3 & $\mathrm{r}$ & $2 / 52$ \\
\hline 75 & Sonchus asper (L.) Hill & $\mathrm{H}$ & 3.5 & $\mathrm{cr}$ & $3 / 52$ \\
\hline 76 & Sonchus oleraceus L. & $\mathrm{H}$ & 3 & $\mathrm{cr}$ & $2 / 52$ \\
\hline 77 & Sorghum halepense (L.) Pers. & $\mathrm{H}$ & 2 & $\mathrm{c}$ & $2 / 52$ \\
\hline 78 & Stellaria media (L.) Vill. & $\mathrm{H}$ & 3 & $\mathrm{cr}$ & $14 / 52$ \\
\hline 79 & Tanacetum vulgare $\mathrm{L}$. & $\mathrm{H}$ & 3.5 & $\mathrm{c}$ & $2 / 52$ \\
\hline 80 & Taraxacum officinale Weber & G & 3 & crs & $3 / 52$ \\
\hline 81 & Torilis arvensis (Huds.) Link & $\mathrm{H}$ & 2 & $\mathrm{cr}$ & $2 / 52$ \\
\hline 82 & Trifolium fragiferum $\mathrm{L}$. & $\mathrm{H}$ & 3 & crs & $2 / 52$ \\
\hline 83 & Trifolium pratense $\mathrm{L}$. & $\mathrm{G}$ & 3 & crs & $3 / 52$ \\
\hline 84 & Trifolium repens $\mathrm{L}$. & $\mathrm{H}$ & 3 & crs & $4 / 52$ \\
\hline 85 & Valerianella spp. & - & - & - & $2 / 52$ \\
\hline 86 & Verbascum thapsus L. & $\mathrm{P}$ & 2.5 & crs & $4 / 52$ \\
\hline 87 & Verbena officinalis L. & $\mathrm{P}$ & 3 & $\mathrm{cr}$ & $8 / 52$ \\
\hline 88 & Veronica persica Poir. & $\mathrm{P}$ & 3 & $\mathrm{cr}$ & $15 / 52$ \\
\hline 89 & Vicia sativa $\mathrm{L}$ & $\mathrm{T}$ & 3 & $\mathrm{cr}$ & $19 / 52$ \\
\hline 90 & Xanthium orientale L. subsp. italicum (Moretti) Greuter & G & 3 & $\mathrm{cr}$ & $4 / 52$ \\
\hline
\end{tabular}




\section{References}

Acutis, M. and Donatelli, M.: SOILPAR 2.00: software to estimate soil hydrological parameters and functions, Eur. J. Agron., 18, 3-4, 373-377, 2002

Allen, R. G., Pereira, L. S., Raes, D., and Smith, M.: Crop evapotraspiration - Guidelines for computing crop water requirements. FAO Irrigation and Drainage Paper 56, FAO - Food and Agriculture Organization of the United Nations, Rome, Italy, available at: http://www.fao.org/docrep/X0490E/X0490E00.htm, (last access: 20 July 2015), 1998.

Baker, L.: Development of class pedotransfer functions of soil water retention - a refinement, Geoderma, 144, 225-230, 2008.

Boeckx, P., van Cleemput, O., and Villaralvo, I.: Methane emission from a landfill and the methane oxidizing capacity of its covering soil, Soil Biol. Biochem., 28, 1397-1405, 1996.

Bouma, J. and van Lanen, H. A. J.: Transfer functions and threshold values: from soil charachteristics to land qualities, Quantified land evaluation procedures, Proceedings of the international workshop on quantified land evaluation procedures held in Washington, D.C. 27 Apr 2 May 1986. ITC, Washington D.C., USA, 1986.

Bracchi, G. and Romani, E.: Checklist aggiornata e commentata della flora della Provincia di Piacenza, Museo Civico di Storia Naturale di Piacenza, Piacenza, Italy, 2010.

Braun-Blanquet, J.: Pflanzensoziologie, 3rd edn., Springer-Verlag, Wien, Austria, 1964

Brevik, E. C., Cerdà, A., Mataix-Solera, J., Pereg, L., Quinton, J. N., Six, J., and Van Oost, K.: The interdisciplinary nature of soil. Soil, 1, 117-129, 2015.

Brooks, R. H. and Corey, A. J.: Hydraulic properties of porous media, Hydrol. Paper 3, Colorado State Univ., Fort Collins, USA, 1964.

Campbell, G. S. and Shiozawa, S.: Prediction of hydraulic properties of soils using particle size distribution and bulk density data, in: Proc. Int. Workshop on Indirect Methods for Estimating the Hydraulic Properties of Unsaturated Soils, edited by: van Genuchten, M. T., Leij, F. J., and Lund, L. J., University of California, Riverside, USA, 317-328, 1992.

Cerdà, A.: The effect of season and parent material on water erosion on highly eroded soil in eastern Spain, J. Arid Environ., 52, 319337,2002

Chen, L., Huang, Z., Gong, J., Fu, B., and Huang, Y.: The effect of land cover/vegetation on soil water dynamic in the hilly area of the Loess Plateau, China, Catena, 70, 200-208, 2007.

Chen, X. W., Wong, J. T. F., Mo, W. Y., Man, Y. B., Ng, C. W. W., and Wong, M. H.: Ecological Performance of the Restored South East New Territories (SENT) Landfill in Hong Kong (20002012), Land. Degrad. Dev., 2015.

Conti, F., Abbate, G., Alessandrini, A., Blasi, C.: An Annotated Checklist of Italian Flora, Palombi and Partner, Rome, Italy, 2005

Doorenbos, J. and Kassam, A. H.: Yield response to water, FAO Irrigation and Drainage Paper 33, FAO - Food and Agriculture Organization of the United Nations, Rome, Italy, 1979.

Elsenbeer, H.: Preface of the Special Issue on pedotransfer functions in hydrology, J. Hydrol., 251, 121-122, 2001.

El-Sheikh, M. A., Al-Sodany, Y. M., Eid, E. M., and Shaltout, K. H.: Ten years primary succession on a newly created landfill at a la- goon of the Mediterranean Sea (Lake Burullus RAMSAR site), Flora, 207, 459-468, 2012.

Famiglietti, J. S., Rudnicki, J. W., and Rodell, M.: Variability in the surface moisture content long a hillslope transect: Rattlesnake Hill, Texas, J. Hydrol., 210, 259-281, 1998.

Fu, B., Wang, J., Chen, L., and Qui, Y.: The effect of land use on soil moisture variation in the Danangou catchment of the Loess Plateau, China, Catena, 54, 197-213, 2003.

Gao, X., Wu, P., Zhao, X., Wang J., and Shi, Y.: Effects of land use on soil moisture variation in a semi-arid catchment: implications for land and agricultural water management, Land Degrad. Dev., $25,163-172,2014$

Gilman, E. F., Leone, I. A., and Flower, F. B.: Influence of soil gas contamination on tree root growth, Plant Soil, 65, 3-10, 1982.

Giupponi, L., Corti, C., and Manfredi, P.: Onopordum acanthium subsp. acanthium in una ex-discarica della Pianura Padana (Piacenza), Informatore Botanico Italiano, 45, 213-219, 2013a.

Giupponi, L., Corti, C., Manfredi, P., and Cassinari, C.: Application of the floristic-vegetational indexes for the evaluation of the environmental quality of a semi-natural area of the Po Valley (Piacenza, Italy), Plant Sociology, 50, 47-56, $2013 \mathrm{~b}$.

Grime, J. P.: Plant Strategies, Vegetation Processes and Ecosystem Properties, John Wiley \& Sons, Chichester, New York, Toronto, 2001.

Grime, J. P.: Plant strategies and vegetation processes, John Wiley $\&$ Sons, Chichester, New York, Brisbane, Toronto, 1979.

Gross, N., Robson, T. M., Lavorel, S., Albert, C., Bagousse-Pinguet, Y. L., and Guillenim, R.: Plant response traits mediate the effects of subaline grassland on soil moisture, New Phytol., 180, 652$662,2008$.

Guber, A. K. and Pachepsky, Y. A.: Multimodeling with Pedotransfer Functions, Documentation and User Manual for PTF Calculator, Environmental Microbial and Food Safety Laboratory, Beltsville Agricultural Research Center, USDA-ARS, 2010.

Gupta, S. C. and Larson, W. E.: Estimating soil water retention characteristics from particle-size distribution, organic matter percent, and bulk density, Water Resour. Res., 15, 1633-1635, 1979.

Haghighi, F., Gorji, M., and Shorafa, M.: A study of the effects of land use changes on soil phisycal properties and organic matter, Land Degrad. Dev., 21, 496-502, 2010.

Hille, D.: Environmental Soil Physics, Academic Press, San Diego, CA, USA, 1998.

Hu, W., Shao, M. A., Han, F. P., Reichardt, K., and Tan, J.: Watershed scale temporal stability of soil water content, Geoderma, 158, 181-198, 2010.

Huber-Humer, M. and Klug-Pümpel, B.: The vegetation on different top covers of an abandoned solid waste landfill, Die Bodenkultur, $55,155-163,2004$.

Keesstra, S. D., Bruijnzeel, L. A., and Van Huissteden, J.: Mesoscale catchment sediment budgets: combining field surveys and modeling in the Dragonja catchment, southwest Slovenia, Earth Surf. Proc. Land., 34, 1547-1561, 2009.

Keesstra, S. D.: Impact of natural reforestation on floodplain sedimentation in the Dragonja basin, SW Slovenia, Earth Surf. Proc. Land., 32, 49-65, 2007.

Landolt, E.: Ökologische Zeigerwerte zur Schweizer Flora, Geobotanisch Institut ETH, Zürich, Switzerland, 1977.

Landolt, E., Bäumler, B., Erhardt, A., Hegg, O., Klötzli, F., Lämmle, R. W., Nobis, M., Rudmann-Mayree, K., Schweingru- 
ber, H. F., Theurillat, J. P., Urmi, E., Vust, M., and Wohlgemuth, T.: Flora indicativa. Ökologische Zeigerwerte und biologische Kennzeichen zur Flora der Schweiz und der Alpen (Ecological indicator values and biological attributes of the Flora of Switzerland and the Alps), Haupt Verlag, Bern-Stuttgart-Wien, 2010.

Leij, F. J., Alves, W. J., van Genuchten, M. T., and Williams, J. R.: Unsatured Soil Hydraulic Database, UNSODA 1.0 User's Manual. Report EPA/600/R96/095, US Environmental Protection Agency, Ada, OK, USA, 103 pp., 1996.

Leij, F. J., Russel, W. B., and Scott, M. L.: Closed-form epressions for water retention and conductivity data, Ground Water, 35, 848-858, 1997.

Li, Z., Liu, W. Z., Zhang, X. C., and Zheng, F. L.: Impacts of land use change and climate variability on hydrology in an agricultural catchment on the Loess Plateau of China, J. Hydrol., 377, 35-42, 2009

Li, X. I., Contreras, S., Sole-Benet, A., Canton, Y., Domingo, F., Lazaro, R., Lin, H., Wesemael, B. V., and Puigdefabregas, J.: Controls of infiltration-runoff processes in Mediterranean karst rangelands in SE Spain, Catena, 86, 98-109, 2011.

Manfredi, P., Giupponi, L., Cassinari, C., Corti, C., Marocco, A., and Trevisan, M.: I caratteri del suolo di un'area degradata: parametri chimici e indicatori ecologici a confronto, EQAbook, 1, 81-88, 2012 (in Italian).

Mayr, T. and Jarvis, N. J.: Pedotransfer functions to estimate soil water retention parameters for a modified Brooks-Corey type model, Geoderma, 91, 1-9, 1999.

Mucina, L., Grabherr, G., and Ellmauer, T.: Die Pflanzengesellschaften Österreichs, Band, 1 - Anthropogene Vegetation, G. Fischer, Jena, 1993 (in German).

Nemes, A., Schaap, M. G., Leij, F. J., and Wösten, J. H. M.: Description of the unsaturated soil hydraulic database UNSODAversion 2, J. Hydrol., 251, 151-162, 2001a.

Nemes, A., Wösten, J. H. M., and Lilly, A.: Development of soil hydraulic pedotransfer functions on a european scale: their usefullness in the assessment of soil quality, in: Sustainig the Global Farm, edited by: Stott, D. E., Mohtar, R. H., and Steinardt, G. C., Selected papers from the 10th International Soil Conservation Organization Meeting held 24-29 May 1999 at Purdue University and the USDA-ARS National Soil Erosion Research Laboratory, 541-549, 2001b.

Nemes, A., Timlin, D. J., Pachepsky, Ya. A., and Rawls, W. J.: Evaluation of the Rawls et al. (1982) Pedotransfer Functions for their Applicability at the US National Scale, SSSAJ, 73, 1638-1645, 2009.

Novara, A., Gristina, L., Saladino, S. S., Santoro, A., and Cerdà, A.: Soil erosion assessment on tillage and alternative soil managements in a Sicilian vineyard, Soil Till. Res., 117, 140-147, 2011.

Oberdorfer, E.: Süddeutsche Pflanzengesellschaften, vol. 3, Gustav Fischer Verlag, Stuttgart, 1993 (in German).

Oosterveld, M. and Chang, C.: Empirical relations between laboratory determinations of soil texture and moisture characteristic, Can. Agr. Eng., 22, 149-151, 1980.

Pachepsky, Y. A. and Rawls, W. J.: Developement of Pedotransfer Functions in Soil Hydrology. Developments in Soil Science, 30, Elsevier, Amsterdam, the Netherlands, 2004.
Pan, X. Y. and Wang, X. P.: Factors controlling the spatial variability of surface soil moisture within revegetated-stbilized desert ecosystems of the Tengger Desert, Northern China, Hydrol. Process., 23, 1591-1601, 2009.

Pignatti, S.: Geobotanica, in: Trattato di Botanica, vol. 2, edited by: Cappelletti, C., UTET, Torino, 801-977, 1976 (in Italian).

Pignatti, S.: Flora d'Italia, vol. 3, Edagricole, Bologna, Italy, 1982 (in Italian).

Pignatti, S.: Ecologia del Paesaggio, UTET, Torino, Italy, 1994.

Pignatti, S., Bianco, P. M., Fanelli, G., Paglia, S., Pietrosanti, S., and Tescarollo, P.: Le piante come indicatori ambientali, manuale tecnico-scientifico, Agenzia Nazionale Protezione Ambiente, Roma, Italy, 2001.

Porporato, A., D’Odorico, P., Laio, F., Ridolfi, L., and RodriguezIturbe, I.: Ecohydrology of water-controlled ecosystems, Adv. Water Resour., 25, 1335-1348, 2002.

Puppi, G., Speranza, M., Ubaldi, D., and Zanotti, A. L.: Le serie di vegetazione della regione Emilia-Romagna, in: La Vegetazione d'Italia, edited by: Blasi, C., Palombi and Partner, Roma, Italy, 181-203, 2010.

Qui, Y., Fu, B. Y., Wang, J., and Chen, L. D.: Spatial variability of soil moisture content and its relation to environmental indices in a semi-arid gully catchment of the Loess Plateau, China, J. Arid Environ., 49, 723-750, 2001.

Rajkai, K. and Varallyay, G.: Estimating soil water retention from simpler properties by regression techniques, in: Proc. Int.Workshop on Indirect Methods for Estimating the Hydraulic Properties of Unsaturated Soils, edited by: van Genuchten, M. T., Leij, F. J., and Lund, L. J., University of California, Riverside, USA, 417-426, 1992.

Raunkiaer, C.: The Life Forms of Plants and Statistical Plant Geography, The Clarendon Press, Oxford, UK, 1934.

Rawls, W. J. and Brakensiek, D. L.: Prediction of soil water properties for hydrologic modeling, in: Proc. Symp. Watershed Management in the Eighties, edited by: Jones, E. B. and Ward, T. J., Denver, CO, 30 Apr-1 May 1985, Am. Soc. Civ. Eng., New York, 293-299, 1985.

Rawls, W. J., Brakensiek, D. L., and Saxton, K. E.: Soil water characteristics, T. ASAE, 25, 1316-1328, 1982a.

Rawls, W. J., Brakensiek, D. L., and Saxton, K. E.: Estimation of soil water properties, T. ASAE, 25, 1316-1320, 1982 b.

Rawls, W.J, Brakensiek, D. L., and Soni, B.: Agricultural management effects on soil water processes, Part I, Soil water retention and Green-Ampt parameters, T. ASAE, 26, 1747-1752, 1983.

Rawls, W. J., Ahuja, L. R., Brakensiek, D. L., Shirmohammadi, A.: Infiltration and soil water movement, in: Handbook of Hydrology, edited by: Maidment, D. R., McGraw-Hill, New York, NY, USA, 5.1-5.51, 1992.

Rawls, W. J., Gimenez, D., and Grossman, R.: Use of soil texture, bulk density and slope of the water retention curve to predict saturated hydraulic conductivity, T. ASAE, 41, 983-988, 1998.

Rebele, F. and Lehmann, C.: Restoration of a landfill site in Berlin, Germany by spontaneous and directed succession, Restor. Ecol., 10, 340-347, 2002.

Rodriguez-Iturbe, I., D’Odorico, P., Porporato, A., and Ridolfi, L.: On the spatial and temporal links between vegetation, climate, and soil moisture, Water Resour. Res., 35, 3709-3722, 1999.

Rodriguez-Iturbe, I., Porporato, A., Laio, F., and Ridolfi, L.: Plants in water-controlled ecosystems: Active role in hydrologic pro- 
cesses and response to water stress I. Scope and general outline, Adv. Water. Resour., 24, 695-705, 2001.

Romani, E. and Alessandrini, A.: Flora Piacentina. Museo Civico di Storia Naturale di Piacenza, Piacenza, Italy, 2001.

Romano, N. and Palladino, M.: Prediction of soil water retention using soil physical data and terrain attributes, J. Hydrol., 265, 56-75, 2002.

Saxton, K. E. and Rawls, W. J.: Soil water characteristic estimates by texture and organic matter for hydrologic solutions, Soil Sci. Soc. Am. J., 70, 1569-1578, 2006.

Saxton, K. E. and Willey, P. H.: The SPAw model for agricoltural field and pond hydrologic simulation, in: Mathematical Modeling of Watershed Hydrology, edited by: Singh, V. P. and Frevert, D., CRC Press, USA, 401-435, 2006.

Saxton, K. E., Rawls, W. J., Romberger, J. S., and Papendick, R. I.: Estimating generalized soil-water characteristics from texture, Soil Sci. Soc. Am. J., 50, 1031-1036, 1986.

Schaap, M. G., Leij, F. J., and van Genuchten, M. T.: ROSETTA: a computer program for estimating soil hydraulic parameters with hierarchical pedotransfre functions, J. Hydrol., 251, 163176, 2001.

Simunek, J., Sejna, M., Saito, H., and van Genuchten, M. T.: The Hydrus-1-D software package for simulating the movement of water, heat and multiple solutes in variably saturated media, version 4., HYDRUS software series 3. Department of Environmental Sciences, University of California Riverside, Riverside, p 315 , 2008.

Sukopp, H. and Werner, P.: Urban environments and vegetation, in: Man's Impact on Vegetation, edited by: Holzner, W., Werger, M. J. A., and Ikusima, I., The Hague, Junk, 247-260, 1983.

Tanij, K. K.: Agricultural Salinity Assessment and Management, Am. Soc. Civ. Eng., New York, NY, USA, 1990.

Tapkenhinrichs, M. and Tietje, O.: Evaluation of pedo-transfer functions, Soil Sci. Soc. Am. J., 57, 1088-1095, 1993.

Themelis, N. J. and Ulloa, P. A.: Methane generation in landfills, Renew. Energ., 32, 1243-1257, 2007.

Tietje, O. and Hennings, V.: Accuracy of the saturated hydraulic conductivity prediction by pedo-transfer functions compared to the variability within FAO textural classes, Geoderma, 69, 7184, 1996.

Tomasella, J. and Hodnett, M. G.: Estimating soil water retention characteristics from limited data in Brazilian Amazonia, Soil Sci., 163, 190-202, 1998.

Ubaldi, D.: Le vegetazioni erbacee e gli arbusteti italiani, tipologie fitosociologiche ed ecologia, Aracne, Roma, Italy, 2008.

Vachaud, G., Passerat de Silans, A., Balabanis, P., and Vauclin, M.: Temporal stability of spatially measured soil water probability density function, Soil Sci. Soc. Am. J., 49, 822-828, 1985.

van Genuchten, M. T.: A closed-form equation for predicting the hydraulic conductivity of unsaturated soils, Soil Sci. Soc. Am. J., 44, 892-898, 1980. van Leeuwen, J. P., Lehtinen, T., Lair, G. J., Bloem, J., Hemerik, L., Ragnarsdóttir, K. V., Gísladóttir, G., Newton, J. S., and de Ruiter, P. C.: An ecosystem approach to assess soil quality in organically and conventionally managed farms in Iceland and Austria, Soil, 1, 83-101, 2015.

Varallyay, G., Rajkai, K., Pachepsky, Y. A., and Shcherbakov, R. A.: Mathematical description of soil water retention curve, Pochvovedenie, 4, 77-89, 1982.

Vereecken, H., Weynants, M., Javaux, M., Pacheepsky, Ya.A., Schaap, M.G., van Genuchten, M.Th.: Using pedotransfer functions to estimate the van Genuchten-Mualem soil Hydraulic properties: a rewiew. Vadose zone J. 9: 1-26, 2010.

Vereecken, H., Maes, J., Feyen, J., and Darius, P.: Estimating the soil moisture retention characteristics from texture, bulk density and carbon content, Soil Sci., 148, 389-403, 1989.

Vereecken, H., Weynants, M., Javaux, M., Pacheepsky, Ya. A., Schaap, M. G., and van Genuchten, M. T.: Using pedotransfer functions to estimate the van Genuchten-Mualem soil Hydraulic properties: a rewiew, Vadose Zone J., 9, 1-26, 2010.

Vermang, J., Demeyer, V., Cornelis, W. M. and Gabriels, D.: Aggregate stability and erosion response to antecedente water content of a loess soil, Soil Sci. Soc. Am. J., 73, 718-726, 2009.

Williams, J., Ross, P., and Bristow, K.: Prediction of the Campbell water retention function from texture, structure, and organic matter, in: Proc. Int. Workshop on Indirect Methods for Estimating the Hydraulic Properties of Unsaturated Soils, edited by: van Genuchten, M. T., Leij, F. J., and Lund, L. J., University of California, Riverside, 427-442, 1992.

Wong, J. T. F., Chen, X. W., Mo, W. Y., Man, Y. B., Ng, C. W. W., and Wong, M. H.: Restoration of plant and animal communities in a sanitary landfill: a ten years case study in Hong Kong, Land Degrad. Dev., doi:10.1002/ldr.2402, in press, 2015.

Wösten, J. H. M., Lilly, A., Nemes, A., Le Bas, C.: Development and use of a database of hydraulic properties of European soils, Geoderma, 90, 169-185, 1999.

Wösten, J. H. M., Pachepsky, Ya. A., and Rawls, W. J.: Pedotransfer functions: bridging the gap between available basic soil data and missing soil hydraulic characteristics, J. Hydrol., 251, 123-150, 2001.

Wösten, J. H. M. and Lilly, A.: Hydraulic Properties of European Soils - HYPRES, available at: http://www.macaulay.ac.uk/ hypres/, last access: 12 February 2015, 2004.

Zhao, G., Mu, X., Wen, Z., Wang, F., and Gao, P.: Soil erosion, conservation, and Eco-environment changes in the Loess Plateau of China. Land Degrad. Dev., 24, 499-510, 2013.

Ziadat, F. M. and Taimeh, A. Y.: Effect of rainfall intensity, slope and land use and antecedent soil moisture on soil erosion in an arid environment. Land Degrad. Dev., 24, 582-590, 2013.

Zornoza, R., Acosta, J. A., Bastida, F., Domínguez, S. G., Toledo, D. M., and Faz, A.: Identification of sensitive indicators to assess the interrelationship between soil quality, management practices and human health. Soil, 1: 173-185, 2015. 